\title{
Assessment of Teaching and Learning in Dynamics
}

\author{
Julie Y.-Z. Wang and Oguz Soysal \\ Frostburg State University
}

\begin{abstract}
This paper presents a process to directly assess the ${ }^{1} \mathrm{ABET}$ learning outcomes at a course level in Dynamics. The outcomes from the student performance show that the mathematics and physics preparation is an important factor to succeed the Dynamics course. The interactive activities in the class improve the quality of teaching/learning. The standard lecture/tutorial format of traditional instruction in the class is replaced by a series of two-hour active-learning sessions involving short lectures and demonstrations, problem solving, classroom questioning and discussion. Students are involved in the class activities, peer tutorial, and discussion of the exercise problems and real world examples.

The assessment includes course surveys from the students, the scores on the quizzes and tests and final exams. The result shows the student strength and limitation in the areas of mathematics, physics and engineering science. The paper presents the result from the course assessment and the plans for continuous improvement to achieve ABET learning outcomes and objectives in mechanical engineering program.
\end{abstract}

\section{Introduction}

The course ENES 221 - Dynamics is a fundamental course in mechanics for sophomore mechanical engineering students at Frostburg State University. The prerequisites for this course are Calculus II and Statics. The basic concepts in this course are the Newton's law and its applications, the kinematics of particles in various coordinate systems, workenergy relation and impulse-momentum, as well as the principles to determine the plane translation and rotation of rigid bodies in various coordinates

The course of dynamics has its roots in mathematics and physics. It is based on the knowledge and skills acquired in the earlier course work such as Calculus I and II, Physics I-mechanics, and Statics, while Dynamics carries further toward creative applications, and provides a bridge between mathematics/sciences and the engineering practice.

To assess the quality of teaching/learning at a course level, the ABET processes for the evaluation, assessment, and continuing improvement of the course include: setting up assessment goals, developing course objectives, developing detailed course outcomes, collecting student performing data, analyzing and evaluating result, and continuing the cycle for the improvement according to ABET criteria ${ }^{2}$. An assessment process and methods for the direct assessment of ABET outcomes in Dynamics are addressed in this paper. 


\section{Set up course assessment goals}

To assess student's preparations in mathematics and physics

To assess student's knowledge and skills attained through the course.

To evaluate the instruction effective overall effectiveness of the course

To continue for improvement of the courser based on the assessment outcomes.

\section{Develop detailed course objectives}

The course objectives for students are to understand the fundamental principles and concepts of kinematics and kinetics with their applications in particles and rigid-bodies mechanical system. The learning objectives are

1. The knowledge of kinematics: linear motion, curvilinear motion and gravitational free-fall;

2. The knowledge of Newton's laws and friction;

$3 . \quad$ The knowledge of work energy, energy conservation;

4. The knowledge of impulse-momentum and momentum conservation;

5. Reinforcement of mathematics and physics science concepts and skills;

6. Effective communication including drawing, calculating, and problem solving skills.

\section{Course outcomes related to the ABET criteria}

A detailed set of course outcomes has been developed for Dynamics course. These course outcomes will be used to determine the effectiveness of teaching/learning process in achieving the program outcomes. It fulfills outcomes a, e, g, I, and $\mathrm{k}$ in ${ }^{\mathrm{I}} \mathrm{ABET}$ Criterion 3 (a-k), and it has consistency with the program mission, the objectives and the curriculum outcomes. The students are expected to demonstrate the following learning outcomes:

1. (a) An ability to apply knowledge of mathematics, science, and engineering

- Mathematics foundations: To be able to use derivatives and integrals for solving mechanics problems in a variety of coordinate systems.

- Scientific foundations: To be able to use applied scientific knowledge to solve problems in mechanical engineering and related fields.

- Engineering foundations: To be able to use fundamental kinematics and kinetics principles to solve problems in mechanical engineering systems.

2. (e) An ability to identify, formulate, and solve engineering problems.

- To be able to use equations for solving problems

- To be able to perform calculations with both SI and English units systems;

3. (g) An ability to communicate effectively

To be able to draw a free body diagram, derive engineering solution logically, 
use engineering problem solving format, and present the ideas in the group discussion.

4. (i) A recognition of the need for, and an ability to engage in life-long learning To be able to obtain self-learning skills, read book, study examples and solve the problems.

5. (k) an ability to use the techniques, computer skills, and modern engineering tools necessary for engineering practice.

To be able to present a professional quality in a written engineering work.

Table 1 Course objectives and their relationship to ABET/Course outcomes

\begin{tabular}{|l|l|l|l|l|l|l|l|l|l|l|l|l|}
\hline \multirow{2}{*}{$\begin{array}{l}\text { ENES 221 Dynamics } \\
\text { Course objectives }\end{array}$} & \multicolumn{7}{|l|}{ ABET/ Course Outcomes } \\
\hline & a & b & c & d & e & f & g & h & i & j & k \\
\hline 1. Knowledge of kinematics & X & & & & X & & & & & & \\
\hline 2. Knowledge of Newton's laws & X & & & & X & & & & & & X \\
\hline $\begin{array}{l}\text { 3. Knowledge of work energy, energy } \\
\text { conservation }\end{array}$ & X & & & & X & & & & & & X \\
\hline $\begin{array}{l}\text { 4. Knowledge of impulse-momentum and } \\
\text { momentum conservation }\end{array}$ & X & & & & X & & & & & & X \\
\hline $\begin{array}{l}\text { 5. Reinforcement of mathematics and } \\
\text { physics science concepts and skills }\end{array}$ & X & & & & & & & & X & & \\
\hline 6. Effective communication & & & & & & & X & & & & X \\
\hline
\end{tabular}

The letter of each outcome refers to the relevant ABET program criterion 3 (a-k) outcomes ${ }^{1}$.

\section{Select course assessment tools}

The student work is an important part of the course assessment. An assessment tool is a piece of student work that can be uniquely identified with the course outcomes. Examples may include one or more of the following: an individual quiz or an exam question, an individual laboratory assignment, a project assignment, or an individual homework problem $^{2}$.

Table 2 Assessment tools and their relationship to the course learning outcomes

\begin{tabular}{|l|l|l|l|l|l|l|l|}
\hline \multirow{2}{*}{ Assessment Tools } & \multicolumn{6}{|l|}{ Course Learning Outcomes } \\
\cline { 2 - 9 } & a & e & g & i & k \\
\hline & Math & Physics & Engineering & & & & \\
\hline 1. Test 1 - Problem 1 & X & & & X & & & \\
\hline 2. Quiz 5 & & X & & X & & & \\
\hline 3. Test 3 (Take home) & X & X & X & X & X & X & X \\
\hline 4. Final exam & X & X & X & X & & & \\
\hline
\end{tabular}


All ratings are converted to a zero-to-four scale. For the assessment of effectiveness of prerequisites, the student mathematics and physics data are converted from a letter grade A, B, C, or D to a grade point average of scale 4 . They will be analyzed to indicate the distribution of student performance for the course outcomes.

Problem 1 in Test 1 is selected for measuring the students' mathematics ability to solve kinematics problems for a particle. The problem includes the performance of derivatives and integrations for acceleration, velocity and position vectors. This assessment tool is selected because it reflects student's mathematical background and also it represents the mathematical level required in this course.

Quiz 5 problem is selected for measuring the students' knowledge of physics in momentum and impulse for a particle. This problem clearly defines the relationship between linear impulse and momentum. The problem is in the format of Fundamentals of Engineering Exam.

Test 3 is a take-home test. It is designed for measuring student's self-learning and critical thinking abilities. It measures the level of the knowledge that student have learned in kinematics and kinetic problems of rigid-bodies. Students have to give a complete solution following the engineering problem-solving format, so the effectiveness of communication is also measured.

Final exam is a comprehensive exam. It covers the major topics that student should attain in the course. It is a measurement between the course objectives and outcomes. There are eight problems, six out of the eight were the problems given in the final exam in fall 2004. The outcomes are used to compare with the final exam in fall 2005 to show the continue improvement for this course.

\section{Assessment result}

In all the figures shown below, each group of the columns represents the scale of score from 1 to 4 for each student. The order of the student number is based on the order of the final exam scores. Student number 1 has the lowest score, and student number14 has the highest score in the final exams.

The results from assessment tools 1, 2, 3, and final exam are shown in Figure 1. The groups of columns display the performance for each student on these four assessment tools. Figure 2 shows the math and physics preparation against the final exam score for each student. In comparison with Figure 1 and Figure 2, we can find that the mathematics and physics preparations affect the student performance in Dynamics. Most students have over all consistency with their performances, the better preparation results in a better performance. The higher scores in the problem 1 and quiz 5 are achieved through student activities. The group discussion and class exercises were carried on these 
topics before the test. The students have lower scores on these two topics, either because of the weak preparation in math/physics or because of not attending the class regularly.

Figure 1 Student performance data from four assessment tools in 2005

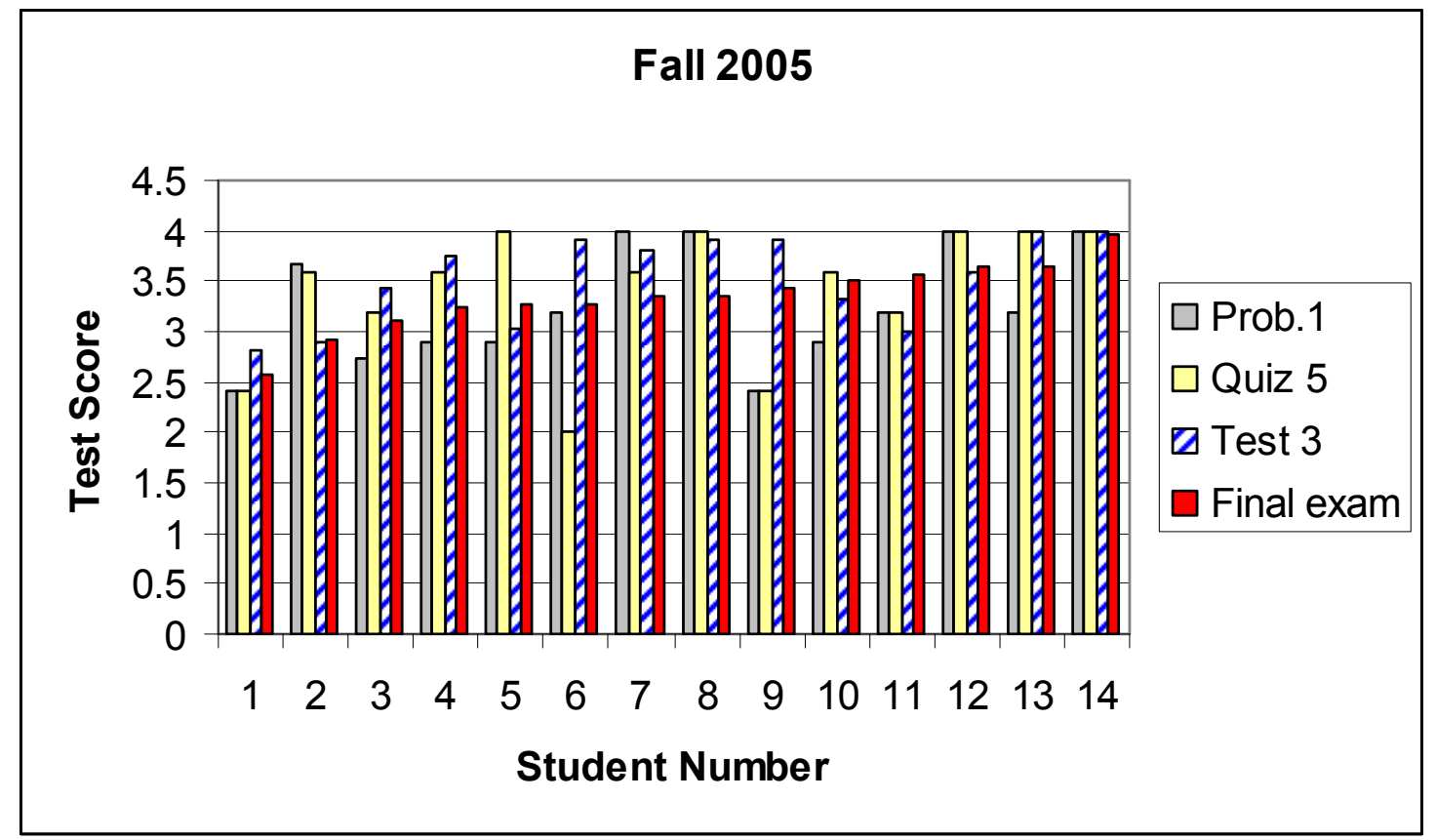

Figure 2 Student mathematic and physics preparation and final exam data in 2005

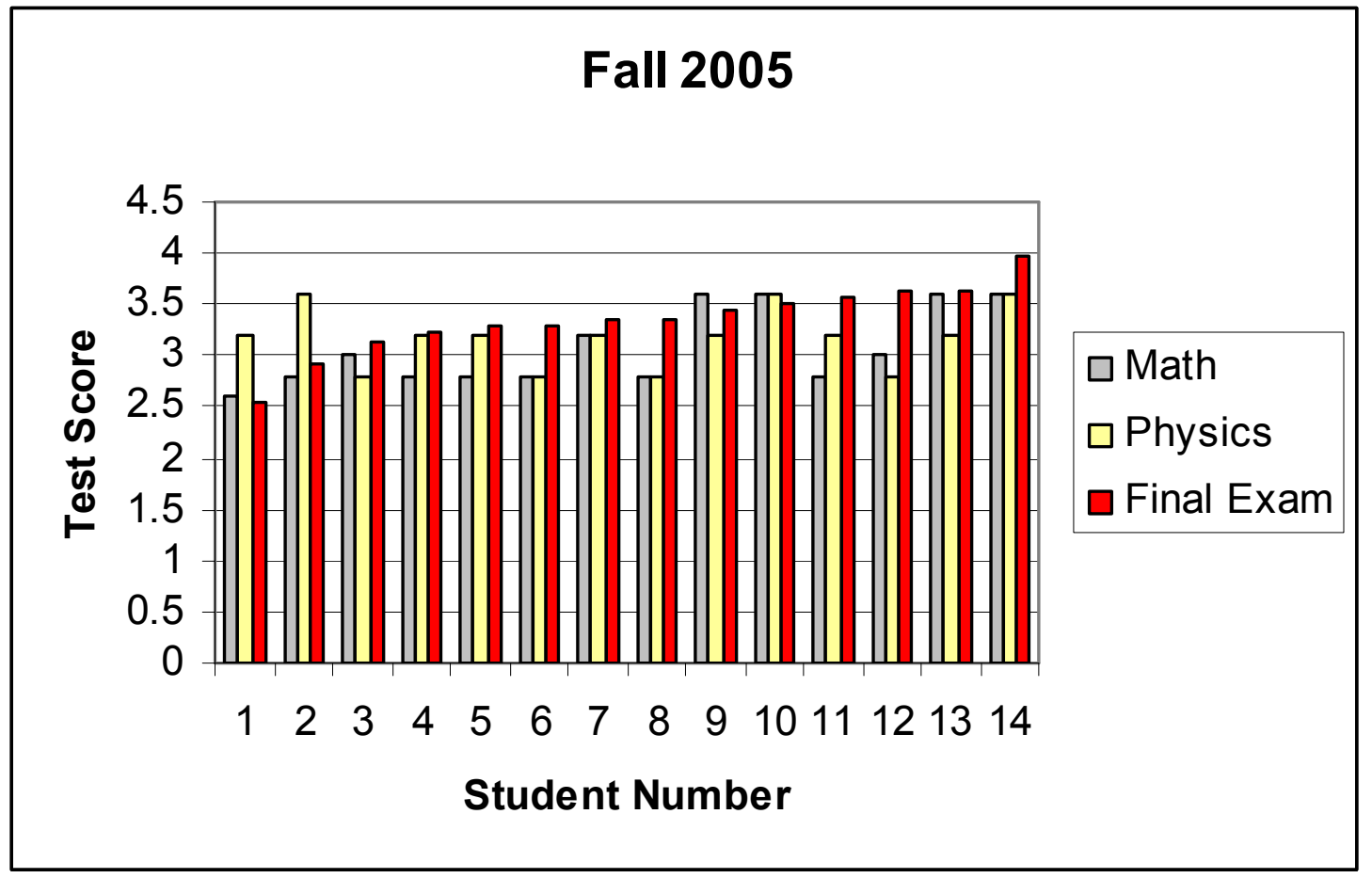


Figure 3 Student mathematics and physics preparation and final exam data in 2004

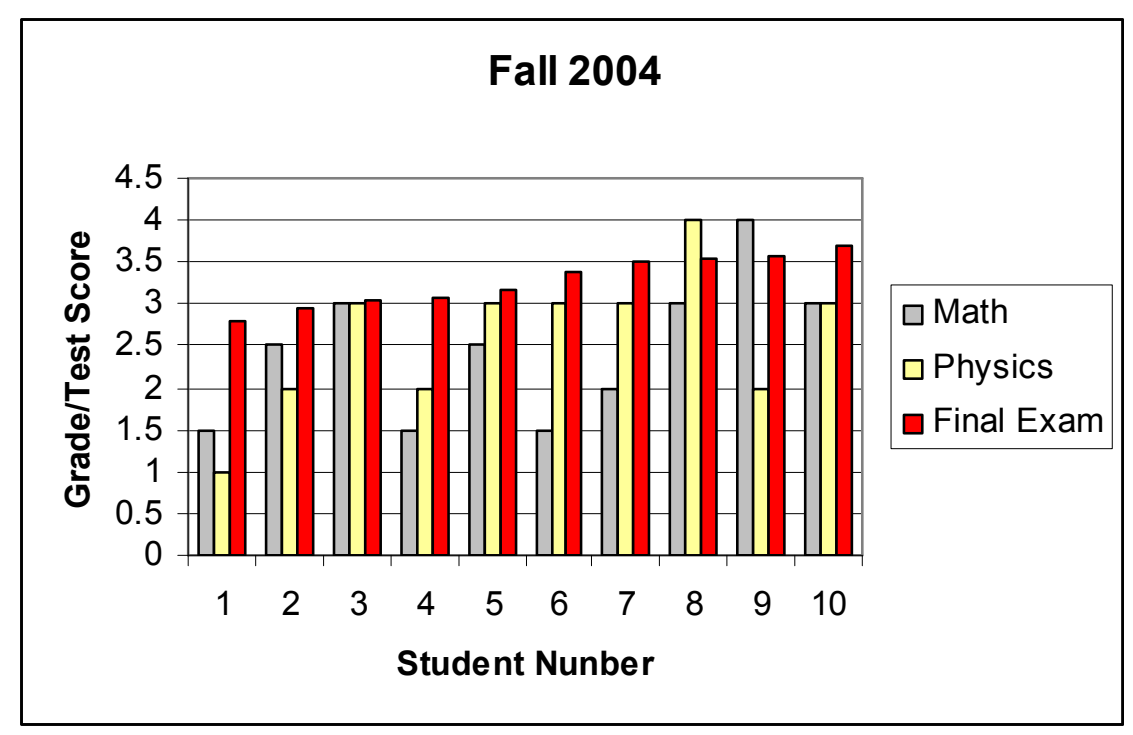

Table 3 Comparison of average score for 2004 and 2005

\begin{tabular}{|l|c|c|c|}
\hline & Calculus I and II & Physics 1: Mechanics & Final Exam \\
\hline 2004 & 2.5 & 2.6 & 3.26 \\
\hline 2005 & 2.7 & 2.9 & 3.35 \\
\hline
\end{tabular}

The key issue in the assessment based on the outcomes is to understand the information contained in the data. Since the data were collected under the certain conditions, specific considerations have to be given. For example, the average score in the take-home test is higher than the scores from other assessment tools, the reasons could be that the students had more time to study and finish the test, or some students got an extra help. The purpose for this test is not just to increase the degree of difficulty for the problems, but also to measure the student's ability to have life-long study skills and to be able to do a professional work. The free body diagrams, the logical problem solving steps, and the written format are the elements for the evaluation and are a part of the score. The column graphics in Figure 1 and 2 give a qualitative views of that the students' scores in test 3 are still based on their math and physics background. In order to improve student's learning, the math skills should be emphasized through out the course.

Table 3 shows the comparison of student preparation on math and physics and the final exams average scores on a continuous two-term basis. It shows the improvement in the final exams between 2004 and 2005. One of the reasons for improvement is getting students involved.

\section{Student surveys}


As a part of the assessment process, a student feedback survey can be used to assess the instructor's performance in the courses. The instructor uses this tool to improve the methods of teaching and interacting with the students.

In fall 2004, most time of the class was given to the lectures during two hours class period. In fall 2005, the interactive activities for teaching/learning are implemented to the class. Table 4 is the result from a survey. Eleven students did the survey. An example of the survey is used to access the teaching methods, for example, one question was "what is the better way for you to understand the concepts in impulse and momentum?" As the result shown, students like the way that can get them involved.

Table $4 \quad$ Surveys to assess teaching/learning methods

\begin{tabular}{|l|l|l|l|}
\hline Learning method & Strongly agree & Somewhat & Disagree \\
\hline Lecture & 6 & 3 & 2 \\
\hline Solving more problems by hands in class & 7 & 3 & 1 \\
\hline Group discussion: solve a typical problem & 5 & 3 & 3 \\
\hline Self study, not go to class & 1 & 5 & 5 \\
\hline
\end{tabular}

At the end of the semester, a qualitative analysis of the results from student performance assessment, the course surveys, and along with other pertinent information will be used to determine which course outcomes need to be improved and provide a plan towards that improvement.

\section{Continuous improvement process}

Table 5 is a list of changes based on the outcomes assessment ${ }^{2}$. It includes the issues that should be addressed based on the outcomes, the plan for the improvement, the changes made on outcomes. The continue improvement will be carried on of teaching/learning in the next term.

Table 5 The assessment plan for continuous improvement

\begin{tabular}{|l|l|l|l|l|}
\hline Year & Issue & Reason initiated & Solution & Result in 2005 \\
\hline 2004 & $\begin{array}{l}\text { Strengthen math } \\
\text { preparation }\end{array}$ & $\begin{array}{l}\text { Mistakes in } \\
\text { calculation of } \\
\text { kinematics }\end{array}$ & $\begin{array}{l}\text { Review derivatives } \\
\text { and integrals }\end{array}$ & $\begin{array}{l}\text { Assessment tool } \\
1 \text { shows the } \\
\text { improvement }\end{array}$ \\
\cline { 2 - 5 } & $\begin{array}{l}\text { Concept between } \\
\text { mass and weight }\end{array}$ & $\begin{array}{l}\text { Confusion in } \\
\text { English units }\end{array}$ & $\begin{array}{l}\text { The teaching } \\
\text { strategy }{ }^{3} \text { convincing } \\
\text { students that gravity } \\
\text { is a force }\end{array}$ & $\begin{array}{l}\text { Final exam } \\
\text { shows } \\
\text { improvement }\end{array}$ \\
\cline { 2 - 5 } & $\begin{array}{l}\text { Lecture in most } \\
\text { class time }\end{array}$ & $\begin{array}{l}\text { Not learning } \\
\text { effectively } \\
\text { interactive activities }\end{array}$ & $\begin{array}{l}\text { Quizzes, and } \\
\text { Test scores } \\
\text { show } \\
\text { Improvement }\end{array}$ \\
\hline
\end{tabular}




\begin{tabular}{|c|c|c|c|c|}
\hline & $\begin{array}{l}\text { Make changes on } \\
\text { the learning } \\
\text { outcomes in } \mathrm{i}\end{array}$ & $\begin{array}{l}\text { Lack of self-study } \\
\text { skills }\end{array}$ & $\begin{array}{l}\text { Give a assignment } \\
\text { with a degree of } \\
\text { difficulty }\end{array}$ & $\begin{array}{l}\text { Take-home } \\
\text { exam is an } \\
\text { example. }\end{array}$ \\
\hline \multirow[t]{5}{*}{2005} & Issue & Reason initiated & Solution & Result in 2006 \\
\hline & $\begin{array}{l}\text { Strengthen math } \\
\text { preparation }\end{array}$ & $\begin{array}{l}\text { Need to Improve } \\
\text { math skills in } \\
\text { various } \\
\text { coordinate } \\
\text { systems }\end{array}$ & $\begin{array}{l}\text { Review derivatives } \\
\text { and integration in } \\
\text { Cartesian, cylindrical, } \\
\text { polar systems }\end{array}$ & \\
\hline & $\begin{array}{l}\text { Effective teaching } \\
\text { /learning }\end{array}$ & $\begin{array}{l}\text { Results from the } \\
\text { student surveys }\end{array}$ & $\begin{array}{l}\text { More hands on } \\
\text { problem solving } \\
\text { exercises }\end{array}$ & \\
\hline & $\begin{array}{l}\text { Written } \\
\text { communication } \\
\text { skills }\end{array}$ & $\begin{array}{l}\text { Student written } \\
\text { work is difficult } \\
\text { to read and follow }\end{array}$ & $\begin{array}{l}\text { Add effective } \\
\text { communication as a } \\
\text { part of outcomes }\end{array}$ & \\
\hline & $\begin{array}{l}\text { Change of } \\
\text { learning } \\
\text { outcomes }\end{array}$ & $\begin{array}{l}\text { Responsibility: } \\
\text { commitment to } \\
\text { learning }\end{array}$ & $\begin{array}{l}\text { Discuss the issue } \\
\text { A survey, e.g., how } \\
\text { many hours they } \\
\text { spent for study. }\end{array}$ & \\
\hline
\end{tabular}

\section{Conclusion}

The paper has presented a process of assessment of ABET outcomes on a course level. It is expected to improve effectiveness and efficiency of the ABET processes. The quality of the assessment relies on the instructor efforts to achieve the course outcomes. We hope that the assessment could improve teaching and learning process, and it could better serve continuous improvement in accomplishing the ABET program learning outcomes and objectives.

\section{References}

1. Criteria for Accrediting Engineering Programs, Criteria for Effective for Evaluations during the 2006-2007. ABET Board of Directors, 2005. Website: www.abet.org

2. Hadim, H., K. Pochiraju, C. Chassapie, D. Vaccari, K. Sheppard, G. Korfiatis, "Mechanical Engineering Program Assessment in the Schaefer School of Engineering at Stevens Institute of Technology", Proceedings of the 2005 American Society for Engineering Education Annual Conference \& Exposition, Portland, OR, June 2005

3. Hestenes,D. and M. Wells, "A mechanics Baseline Test", The Physics Teacher 30, March, 1992, P.159-166.

4. David Elizandro, Jessica Matson, and Jane Fraser, "ABET Criteria and Continuous Process Improvement", Proceedings of the 2005 American Society for Engineering Education Annual Conference \& Exposition, Portland, OR, June 2005 